\title{
Decolorization of Textile Dying Mill Effluent by using a Bacterial Strain Lysinibacillus boronitolerans CMGS-2
}

\author{
Madhuri R. Basutkar and Channappa T. Shivannavar* \\ Department of Microbiology, Gulbarga University, Kalaburagi-585106, India \\ *Corresponding author
}

\begin{tabular}{|c|}
\hline Keywords \\
\hline $\begin{array}{l}\text { BOD, COD, DO, } \\
\text { PH, TDS, } \\
\text { IMTECH, MTCC, } \\
\text { Poly Urethane } \\
\text { Foams (PUF) }\end{array}$ \\
\hline Article Info \\
\hline $\begin{array}{l}\text { Accepted: } \\
10 \text { May } 2019 \\
\text { Available Online: } \\
10 \text { June } 2019\end{array}$ \\
\hline
\end{tabular}

\section{Introduction}

Industrialization is considered to be the key to development in economic terms. However, it is also recognized to be the root problems from environmental perspective. The recognition that environmental pollution is a worldwide threat to public health has given rise to new initiatives for environmental restoration for both economic and ecological reasons. The industrial effluents contain toxic and hazardous pollutants. Earlier for coloring natural colours were using, best example for the natural color is turmeric, a naturally occurring yellow color dye, it is powerful antiseptic and indigo another natural dye gives cooling effect (Siva, 2007). When these natural dyes were replaced by the synthetic dyes, the actual problem of water pollution was started. The discovery of synthetic dye Mauveine by Perkins in 1856 has provided a tool for the production of wide range of dyes that are color fast and come in a wider color range and brighter shades (Zollinger, 1987). It is estimated that approximately dye discharged by textile processing, primarily belongs around class of Reactive Azo dyes $(36 \%)$, Acid (25\%), Direct (15\%) dyes and 
followed by remaining other classes of dyes (Pandey et al., 2007). Most of the azo dyes are water soluble and readily to absorb through skin contact and inhalation leading to the risk of cancer and allergic reactions, an irritant for the eyes and highly toxic, if inhaled or consumed (Nikulina et al., 1995). Mechanisms of microbial color removal Azo compounds are susceptible to biological degradation under both aerobic and anaerobic conditions (Khehra et al., 2005). In general microbial degradation of azo dyes involves the reductive cleavage of azo bonds $(-\mathrm{N}=\mathrm{N}-)$ with the help of an azoreductase enzyme under anaerobic conditions, and this involves a transfer of four-electrons (reducing equivalents). This then proceeds through two stages at the azo linkage, and in each stage two electrons are transferred to the azo dye, which acts as a final electron acceptor, resulting in dye decolorization and the formation of colorless solutions (Chang et al., 2000).

The resulting intermediate metabolites (e.g., aromatic amines) are then further degraded aerobically or anaerobically (Chang et al., 2001; Pandey et al., 2007). A major mechanism behind biodegradation of synthetic dyes in microbial systems is because of the biotransformation enzymes (Raghukumar et al., 1996).

It is generally recognized that azo reductases play an important role in bacterial dye decolorization (Kuhad et al., 2004). Among synthetic dyes, azo dyes constitute the largest and most versatile class with the greatest variety of colors (Bafana et al., 2009).

The efficiency of dye degradation of microbes is one of the major criteria in selecting the microorganisms for the bioremediation process therefore more and more worker are interested in isolation of microorganisms from the environment which having capacity to degrade efficiently more number of dyes individually and in mixture at higher concentrations. The use of such microorganisms for the removal of recalcitrant dyes from industrial effluents offers considerable advantages; the process is relatively inexpensive, the running costs are low, and the end products of complete mineralization are not toxic).

Thus, biodegradation is a promising approach for the remediation of recalcitrant synthetic dyes present in the wastewater. With the aim of detoxification we tested our desire organism on textile effluents and results studied by using UV-VIS Spectrophotometer (Table 1 and 2).

Decolorisation study of textile effluents from dying industry unit sample

\section{Sampling of effluent sample}

Cloth dying unit effluent (Bright red colored) before dumping was collected and used for the treatment using L. boronitolerans CMGS2.

\section{Treatment process of effluents}

Freshly grown isolate $L$. boronitolerans CMGS-2 in the nutrient broth and PUF immobilized CMGS-2 strain selected for the treatment of textile effluents.

Protocol for the treatment of effluent from the dying industry with isolated CMGS-2 strain

\section{Step-1}

The effluent collected from cloth dyeing unit was taken distributed $100 \mathrm{~mL}$ each in the conical flasks. Out of those first flask kept as control without adding isolated bacterial culture of CMGS-2 and routine observation was done. 
Immobilization of the bacterial isolate on poly urethane foam (PUF)

For the treatment of cloth dying unit effluent the bacterial cells of $L$. boronitolerans CMGS-2 immobilized on the polyurethane foam matrix (PUF). In brief the polyurethane foam was cut into approximately $5 \mathrm{~mm}$ cubes, washed twice with distilled water and autoclaved at $15 \mathrm{lbs}$ pressure for $20 \mathrm{~min}$ and dried.

Then $5 \mathrm{~g}$ sterile foam cubes were placed in $100 \mathrm{~mL}$ of isolate L. boronitolerans CMGS-2 suspensions $\left(9 \times 10^{9} \mathrm{cfu} / \mathrm{mL}\right)$ contained in $500 \mathrm{~mL}$ Erlenmeyer flasks, mixed for $2 \mathrm{hrs}$ with the help of magnetic stirrer, and shaken for $1 \mathrm{hr}$ at $150 \mathrm{rpm}$.

The conical flask left undistributed for 2 more hours. After removal of medium, a saline solution was used to wash the immobilized foam cubes for further studies (Veena et al., 2015).

\section{Step-2(a)}

To the flask containing $100 \mathrm{~mL}$ of effluent and $10 \mathrm{~mL}$ of freshly grown culture CMGS-2 was added. (b) To the flask containing 100 $\mathrm{mL}$ of effluent $5 \mathrm{~g}$ of PUF cubes immobilized with CMGS-2 was added.

\section{Step-3 (a)}

To a flask containing $100 \mathrm{~mL}$ of effluent with $0.1 \%$ yeast extract and $10 \mathrm{~mL}$ of freshly grown culture isolate of CMGS-2 was added. b) To a $100 \mathrm{~mL}$ of effluent containing with $0.1 \%$ yeast extract $5 \mathrm{~g}$ of PUF cubes immobilized with CMGS-2 was added.

All these flasks were incubated for $48 \mathrm{hrs}$ at $35{ }^{\circ} \mathrm{C}$ and reduction of color intensity of effluent was determined by UV-Vis spectrophotometer with respective optical density of dyes. Then calculated the percent decolorization and compared results (Lade et al., 2012; Farhana et al., 2015; Lone et al., 2014).

\section{Decolorisation assay}

$1 \mathrm{~mL}$ of the culture media was withdrawn at different time intervals and was centrifuged at $8000 \mathrm{rpm}$ for $10 \mathrm{~min}$ to separate the bacterial cell mass. After that clear supernatant was used to measure the decolorization of dye at UV visible absorbance spectra. Controls without microorganism were always used. The percentage decolorization was calculated as follows: bacterial concentration was $10^{6}$ per $\mathrm{mL}$ ).

Decolorization $(\%)=[($ Initial AbsorbanceFinal Absorbance)/Initial Absorbance] X 100

Table.1 Treatment of dying effluent by using grown culture of CMGS-2

\begin{tabular}{|l|c|c|}
\hline Raw Sample (Control) & $\begin{array}{c}\text { Raw Sample (Without Yeast } \\
\text { Extract) }\end{array}$ & $\begin{array}{c}\text { Raw Sample (With Yeast } \\
\text { Extract) }\end{array}$ \\
\hline 0\% (Decolorization) & $79.17 \%$ & $89.39 \%$ \\
\hline
\end{tabular}

Table.2 Decolorisation of dying effluent by using immobilized CMGS-2 on PUF

\begin{tabular}{|l|c|c|}
\hline Raw Sample (Control) & $\begin{array}{c}\text { Raw Sample (Without } \\
\text { Yeast Extract) }\end{array}$ & $\begin{array}{c}\text { Raw Sample (With } \\
\text { Yeast Extract) }\end{array}$ \\
\hline 0\% (Decolorisation) & $86.32 \%$ & $94.3 \%$ \\
\hline
\end{tabular}


Fig.1 Wavelength scan of untreated and treated dying effluents

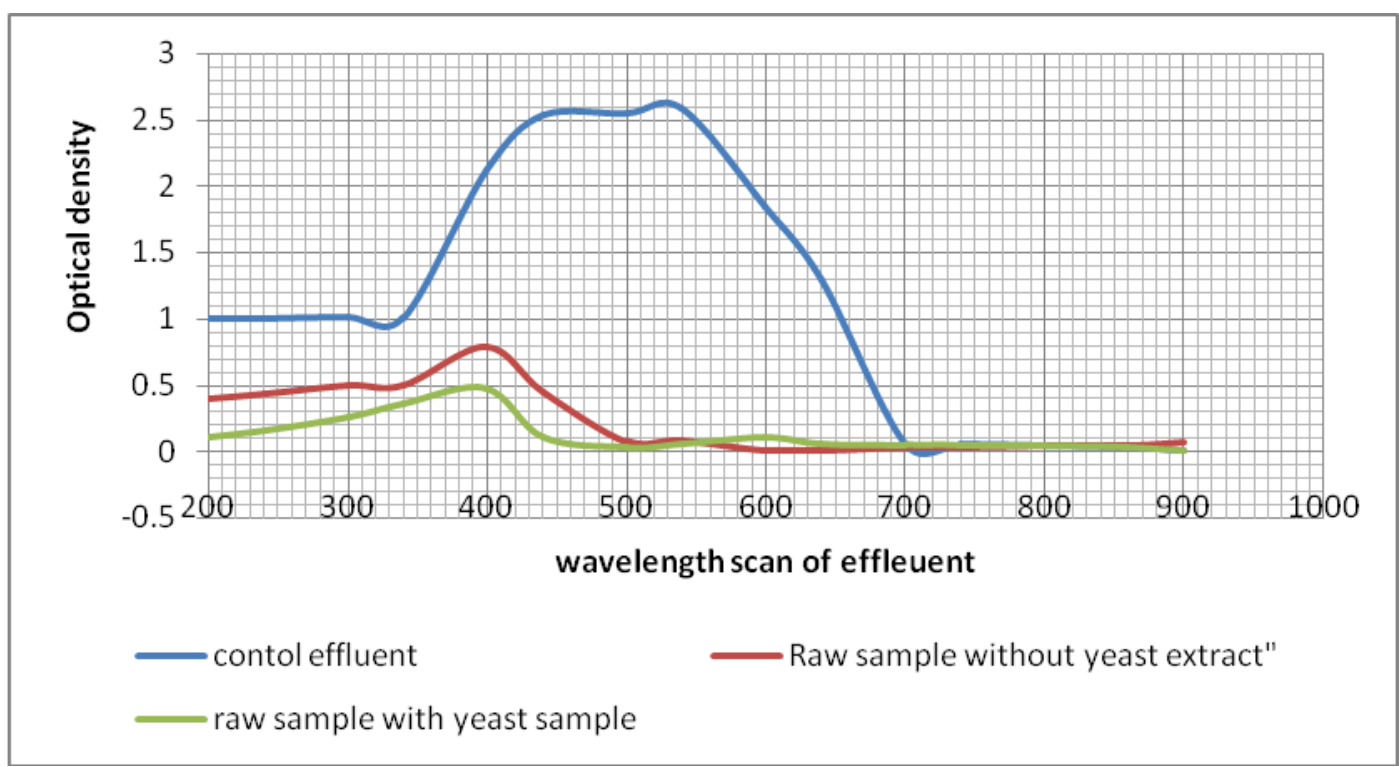

\section{Results of treatment of dying mill effluents}

Effluent sample brought from local cloth dying mill was subjected to decolorization with immobilized and free cells of CMGS-2 following as per (Lone et al., 2014). To the $100 \mathrm{~mL}$ of raw effluent flask added $10 \mathrm{~mL}$ pre grown inoculum of Lysinibacillus boronitolerans CMGS-2 to second flask of that one containing of $0.1 \%$ Y.E.(Yeast extract) (Fig. 1). Similarly to the flask containing $100 \mathrm{~mL}$ of raw effluent (one with $0.1 \%$ Y.E) were added $5 \mathrm{~g}$ of puf immobilized with CMGS-2 were incubated at $45^{\circ} \mathrm{C}$ for 48 hrs. Two flask containing raw effluent (with $0.1 \%$ Y.E) without inoculum served as control effluent treated with immobilized on PUF was shown $94.3 \%$ of decolorization as compared to free cells of CMGS-2 (89.39\%) with yeast extract. However, without Y.E. it was $86.32 \%$ and $79.17 \%$ respectively.

\section{References}

Bafana, A., Chakrabarti, T., Muthal, P. and Kanade, G. (2009). Detoxification of benzidine-based azo dye by $E$. gallinarum: Time-course study.
Ecotoxicol and Environ Safety, 72, 960964.

Chang, J.S., Kuo, T.S., Chao, Y.P., Ho, J.Y. and Lin, P.J. (2000). Azo dye decolorization with a mutant Escherichia coli strain. Biotechnology Letters, 22: 807-812.

Chang, J.S., Chou, C., Lin, Y., Ho, J., Hu, T.L. (2001). Kinetic characteristics of bacterial azo-dye decolorization by Pseudomonas luteola, Water Res., 35:2841-2850.

Farhana Parvin, Muhammed Mizanur Rahman, Md. Mahmudul Islam, Naoshin Jahan, Md. Pallob Ebna Shaekh, Indrani Sarkar, Amit Kumar Dutta and M. Salah Uddin (2015). Isolation of Mixed Bacterial Culture from Rajshahi Silk Industrial Zone and their Efficiency in Azo Dye Decolorization, Indian Journal of Science and Technology, 8(10): 950957.

Khehra, M.S., Saini, H.S., Sharma, D.K., Chadha, B.S. and Chimni, S.S. (2005). Decolorization of various azo dyes by bacterial consortium. Dyes and Pigments, 67:55-61. 
Kuhad, R.C., Sood, N., Tripathi, K.K., Singh, A. and Ward, O.P. (2004). Developments inmicrobial methods for the treatment of dye effluents. Advances in Applied Microbiol, 56:185-213.

Lade, H.S., Waghmode, T.R., Kadam, A.A. and Govindwar, S.P. (2012). Enhanced biodegradation and detoxification of disperse azo dye Rubine GFL and textile industry effluent by defined fungal-bacterial consortium. Int Biodeterior Biodegr., 72:94-107.

Nikulina, G.L., Deveikis, D.N., Pyshnov, G. (1995). Toxicity dynamics of anionic dyes in air of a work place and long term effects after absorption through skin. Med. Tr. Prom. Ekol., 6:25-28.

Pandey, A., Singh, P., Iyengar, L. (2007). Bacterial decolorization and degradation of azo dyes. International Biodeterioration and Biodegradation, 59: 73-84.

Raghukumar, C. (2000). Fungi from marine habitats: An application in bioremediation. Mycology Research,
104:1222-1226.

Siva, R. (2007). Status of natural dyes and dye-yielding plants in India. School of Biotechnology, Chemical and Biomedical Engineering, Vellore Institute of Technology, Vellore 632 014, India.

Tariq Ahmad Lone, Revathi, C. and Reyaz Ahmad Lone (2014). Isolation of dye degrading Pseudomonas species from the soil near dyeing industry erode and its potential application in dye effluent treatment, World $J$ of Pharmacy and Pharmaceutical Sciences, 4(07):12201232. ISSN $2278-4357$.

Veena S. More, Preeti N Tallur, Francois N. Niyonzima and Sunil S. More (2015). Enhanced degradation of pendimethalin by immobilized cells of Bacillus lehensis XJU, 3 Biotech, 5:967-974.

Zollinger, H. (1987). Colour Chemistry: Synthesis, Properties and Applications of Organic Dyes and Pigments, $\mathrm{VCH}$, New York, 92.

\section{How to cite this article:}

Madhuri R. Basutkar and Channappa T. Shivannavar. 2019. Decolorization of Textile Dying Mill Effluent by using a Bacterial Strain Lysinibacillus boronitolerans CMGS-2. Int.J.Curr.Microbiol.App.Sci. 8(06): 1144-1148. doi: https://doi.org/10.20546/ijcmas.2019.806.141 